$12-1988$

\title{
The epidermal growth factor receptor from prostate cells is dephosphorylated by a prostate-specific phosphotyrosyl phosphatase.
}

\author{
Ming-Fong Lin \\ University of Nebraska Medical Center, mlin@unmc.edu \\ Gail M. Clinton \\ Oregon Health Sciences University
}

Tell us how you used this information in this short survey.

Follow this and additional works at: https://digitalcommons.unmc.edu/com_bio_articles

Part of the Medical Biochemistry Commons, and the Medical Molecular Biology Commons

\section{Recommended Citation}

Lin, Ming-Fong and Clinton, Gail M., "The epidermal growth factor receptor from prostate cells is dephosphorylated by a prostate-specific phosphotyrosyl phosphatase." (1988). Journal Articles: Biochemistry \& Molecular Biology. 28.

https://digitalcommons.unmc.edu/com_bio_articles/28

This Article is brought to you for free and open access by the Biochemistry \& Molecular Biology at DigitalCommons@UNMC. It has been accepted for inclusion in Journal Articles: Biochemistry \& Molecular Biology by an authorized administrator of DigitalCommons@UNMC. For more information, please contact digitalcommons@unmc.edu. 


\title{
The Epidermal Growth Factor Receptor from Prostate Cells Is Dephosphorylated by a Prostate-Specific Phosphotyrosyl Phosphatase \\ MING-FONG LIN ${ }^{1}+*$ AND GAIL M. CLINTON 1.2 \\ Departments of Biochemistry ${ }^{1}$ and Medical Genetics, ${ }^{2}$ School of Medicine, The Oregon Health Sciences University, Portland, Oregon 97201
}

Received 22 February 1988/Accepted 2 September 1988

\begin{abstract}
Human prostatic acid phosphatase (PAcP) has been found to have phosphotyrosyl-protein phosphatase activity (H. C. Li, J. Chernoff, L. B. Chen, and A. Kirschonbaun, Eur. J. Biochem. 138:45-51, 1984; M.-F. Lin and G. M. Clinton, Biochem. J. 235:351-357, 1986) and has been suggested to negatively regulate phosphotyrosine levels, at least in part, by inhibition of tyrosine protein kinase activity (M.-F. Lin and G. M. Clinton, Adv. Protein Phosphatases 4:199-228, 1987; M.-F. Lin, C. L. Lee, and G. M. Clinton, Mol. Cell. Biol. 6:4753-4757, 1986). We investigated the molecular interaction of PAcP with a specific tyrosine kinase, the epidermal growth factor (EGF) receptor, from prostate carcinoma cells. Of several proteins phosphorylated in membrane vesicles from prostate carcinoma cells, PAcP selectively dephosphorylated the EGF receptor. The prostate EGF receptor was more efficiently dephosphorylated by PAcP than by another phosphotyrosyl phosphatase, potato acid phosphatase. Further characterization of the interaction of PAcP with the EGF receptor revealed that the optimal rate of dephosphorylation occurred at neutral rather than at acid pH. Thus, the enzyme that we formerly referred to as PAcP we now call prostatic phosphotyrosyl-protein phosphatase. Hydrolysis of phosphate from tyrosine residues in the immunoprecipitated EGF receptor catalyzed by purified prostatic phosphotyrosyl-protein phosphatase caused a 40 to $50 \%$ decrease in the receptor tyrosine kinase activity with angiotensin as the substrate. In contrast, autophosphorylation of the receptor was associated with an increase in tyrosine kinase activity.
\end{abstract}

Tyrosine phosphorylation of cellular proteins is instrumental in the control of cell proliferation mediated by several oncogene protein products and growth factor receptors $(5$, $26,30,52,53)$. Multiple mechanisms for enhanced tyrosine phosphorylation levels have been revealed. Binding of growth factors to their receptors $(26,29)$, alterations in regulatory regions $(2,15,50,60)$, phosphorylation and dephosphorylation $(7,13,14,46,48,62,65,66)$, and amplified levels $(18,61)$ of tyrosine kinases may all lead to elevated tyrosine phosphorylation and to stimulated growth of cells.

Tyrosine phosphorylation may also be elevated when cellular protein phosphatases are inhibited. When orthovanadate, a phosphotyrosyl phosphatase inhibitor, is added to NRK-1 cells, phosphotyrosine levels are elevated up to 40-fold coincident with the induction of several parameters of cell transformation (32). Vanadate also causes accumulation of phosphotyrosine in polyomavirus-transformed cells (64). Although cellular pp $60^{\text {src }}$ has stimulated tyrosine kinase activity when complexed to middle tumor antigen, enhanced cellular phosphotyrosine levels can only be detected when phosphatases are inhibited by the introduction of vanadate to cells (64). Inhibition of phosphatases may also affect the phosphorylation state of the tyrosine kinases. Viral pp $60^{\text {src }}$ (9) and the insulin receptor (58) have both been reported to have increased tyrosine phosphorylation following vanadate treatment of cells.

Tyrosine phosphorylation of the tyrosine kinases has been

\footnotetext{
* Corresponding author.

$\dagger$ Present address: Department of Surgery, Division of Urology and Comprehensive Cancer Center, School of Medicine, University of Southern California, Los Angeles, CA 90033.
}

reported to stimulate $(3,7,48,65,66)$, to inhibit $(13,14)$, or to have no effect $(21,25)$ on the enzyme activity, depending on the particular tyrosine kinase and the site on the kinase that is phosphorylated. For the growth factor receptors, autophosphorylation at tyrosine residues is stimulated by binding of the specific ligand and is generally followed by stimulation of the rate of phosphorylation of exogenous substrate proteins (26). Autophosphorylation of the insulin receptor has been mechanistically coupled to enhanced kinase activity $(48,65,66)$. The results are controversial for the epidermal growth factor (EGF) receptor with reports that autophosphorylation either enhances $(3,59)$ or does not affect $(21,25)$ the kinase activity. If autophosphorylation is directly responsible for stimulation of tyrosine kinase activity, then removal of the phosphate by an appropriate phosphatase should dampen the kinase activity.

Indeed, there is evidence that the EGF receptor may be accessible to phosphotyrosyl phosphatase activity in the human tumor cell line A431. An activity that is inhibited by $\mathrm{Zn}^{2+}(8)$ and by vanadate (57) has been found to remove phosphate from the autophosphorylated EGF receptor in solubilized membrane vesicles. The identity of this phosphatase(s) is not yet established. Moreover, the effect of this phosphatase(s) on the kinase activity of the EGF receptor or its specificity for the EGF receptor have not been explored.

Despite the potential importance of the phosphotyrosyl phosphatases, they are poorly understood. Available information indicates that there are several distinct enzymes that are expressed in different tissues $(1,6,23,34,37,38)$. While most of the phosphotyrosyl phosphatase activity in different cell types and tissues has been recovered in the cytosol $(24$, $37,44,54)$, it has been suggested that cytosolic forms are derived by proteolysis of membrane-bound phosphatases 
(49). The different phosphotyrosyl phosphatases are distinguished by size, $\mathrm{pH}$ optima for activity, and rates of dephosphorylation of and apparent affinities for various phosphotyrosine-containing proteins and peptides $(1,23,34,39,55)$. A general property of most phosphotyrosyl phosphatases, in contrast to phosphatases that are more active toward phosphoserine and phosphothreonine, is their inhibition by vanadate $(1,23,39,57)$. Because there are several different forms of phosphotyrosyl phosphatases that have been assayed under a variety of conditions, it is difficult to make further definite statements about their general properties and their effectors. A clearer understanding of their properties should develop when purified enzymes and sufficient quantities of physiological substrates become available.

One of the best described phosphotyrosyl phosphatases and one with an exceptionally high affinity $\left(K_{m} \simeq 10^{-9} \mathrm{M}\right)$ for phosphotyrosine-containing proteins is the prostate-specific enzyme, prostatic acid phosphatase (PAcP) $(37,38$; for a review, see reference 39$)$. This phosphatase contains two 50 -kilodalton subunits and exists in several isozyme forms (39). The molecular differences between the different forms have not been determined. Interestingly, PAcP is regulated in prostate cells. It is found at low levels in rapidly growing embryonic tissue $(47,63)$ and in prostate carcinoma cells $(22$, $43,47)$ and is elevated up to 100 -fold in nondividing, welldifferentiated tissue $(47,63)$. Prostate carcinoma cell lines that have different levels of PAcP are available $(27,40,56)$. The activity of PAcP in cells can be further regulated by androgens $(27,28,40,63)$. Studies on cells with different PAcP activities have indicated an inverse correspondence with cellular phosphotyrosine levels and tyrosine kinase activity levels (40). Moreover, PAcP has been observed to inhibit overall tyrosine kinase activity, but only from prostate cells with low endogenous PAcP activity (40).

We investigated the molecular interactions of PAcP with a specific tyrosine kinase-the EGF receptor-from prostate carcinoma cells. We show that PAcP selectively dephosphorylated the EGF receptor in membrane vesicles from the prostate carcinoma cell line DU145. The effect of dephosphorylation appeared to be a reduction of the EGF receptor tyrosine kinase activity.

\section{MATERIALS AND METHODS}

Cells. The DU145 cells were derived from metastatic lesions of human prostatic adenocarcinoma and were maintained in RPMI 1640 medium (GIBCO Laboratories, Grand Island, N.Y.) supplemented with $5 \%$ (vol/vol) fetal bovine serum (GIBCO) as described previously (40). The A431 cells were obtained from the American Type Culture Collection (Rockville, Md.).

Preparation of plasma membrane vesicles. The plasma membrane-enriched fractions of DU145 and A431 cells were prepared by the method described by Cohen et al. (12). Cells were induced to vesiculate in a hypotonic buffer, and the shed membrane vesicles were collected by centrifugation. The pelleted vesicles were suspended in $10 \mathrm{mM}$ HEPES $\left(N\right.$-2-hydroxyethylpiperazine- $N^{\prime}$-2-ethanesulfonic acid) $(\mathrm{pH}$ 7.6) containing protease inhibitors including 1.0 trypsin inhibitor unit of aprotinin per $\mathrm{ml}, 2 \mathrm{mM}$ phenylmethylsulfonyl fluoride, and $4 \mu \mathrm{M}$ leupeptin (all from Sigma Chemical Co., St. Louis, Mo.). The suspended vesicles were stored in aliquots at $-70^{\circ} \mathrm{C}$.

Preparation of antibodies. The membrane vesicles prepared from A431 cells, which contain high levels of the EGF receptor, were used to produce the anti-EGF receptor anti- serum by a previously described procedure (10). The first subdermal injection was in complete Freund adjuvant. Four booster subdermal injections were given at 2-week intervals with incomplete Freund adjuvant. The antiserum was heat inactivated at $56^{\circ} \mathrm{C}$ for $1 \mathrm{~h}$ to remove residual serum tyrosine kinase activity (40).

Immunoprecipitation of the EGF receptor. To bind the immunoglobulin G, $5 \mu$ l of heat-inactivated EGF receptor antiserum was mixed with $80 \mu$ l of a $20 \%$ slurry of protein A-Sepharose CL-4B (Sigma) in saline containing $0.1 \%$ Nonidet $\mathrm{P}-40$. The mixture was rotated end-over-end at room temperature for $30 \mathrm{~min}$, and the complex was washed three times with buffer A (20 mM HEPES [pH 7.4], 1\% Triton $\mathrm{X}-100,0.05 \%$ sodium dodecyl sulfate [SDS], $150 \mathrm{mM} \mathrm{NaCl}$, $10 \%$ glycerol) and two times with HEPES-saline $(20 \mathrm{mM}$ HEPES [pH 7.4], $0.9 \% \mathrm{NaCl}$ ). A sample of DU145 membrane vesicles $(40 \mu \mathrm{g}$ of protein) was suspended into an equal volume of membrane buffer (20 mM HEPES [pH 7.4], 5\% Triton X-100, $10 \%$ glycerol), vortexed, and centrifuged at $13,000 \times g$ for $10 \mathrm{~min}$ at $4^{\circ} \mathrm{C}$. The supernatant was diluted fivefold with $10 \mathrm{mM}$ HEPES [pH 7.4] containing protease inhibitors including 1 trypsin inhibitor unit of aprotinin per $\mathrm{ml}, 2 \mathrm{mM}$ phenylmethylsulfonyl fluoride, and $4 \mu \mathrm{M}$ leupeptin and mixed with the anti-EGF receptor antibody complexed to protein A-Sepharose. The mixture was incubated with rotation at $4^{\circ} \mathrm{C}$ for $2 \mathrm{~h}$. The immune complex was washed two times with $1 \mathrm{ml}$ of buffer $\mathrm{A}$ and two times with $1 \mathrm{ml}$ of buffer B (20 mM HEPES [pH 7.6], $10 \mathrm{mM} \mathrm{MnCl}_{2}, 1 \mathrm{mM}$ dithiothreitol, $0.5 \%$ Nonidet $\mathrm{P}-40,25 \mu \mathrm{M}$ sodium orthovanadate [Fisher Scientific Co., Fair Lawn, N.J.]).

Autophosphorylation of the EGF receptor. The washed immune complex containing the EGF receptor was incubated with $10 \mu$ l of $1 \mu \mathrm{M}$ EGF (Collaborative Research, Inc., Waltham, Mass.) at room temperature for $10 \mathrm{~min}$ and then phosphorylated by the addition of the tyrosine kinase reaction mixture (described below) containing $20 \mu \mathrm{M}$ ATP in the absence of angiotensin. After incubation on ice for $10 \mathrm{~min}$, the immune complex was removed from the reaction mixture by centrifugation and was washed twice with buffer $\mathrm{A}$ and twice with HEPES-saline at $4^{\circ} \mathrm{C}$. The autophosphorylated EGF receptor was then ready for dephosphorylation by prostatic phosphotyrosyl-protein phosphatase (PrPYP) or for tyrosine protein kinase assays with angiotensin as the substrate.

Dephosphorylation of EGF Receptor by PrPYP. A sample of highly purified PrPYP (38) dissolved in $5 \mu$ l of saline was added to the EGF receptor-antibody complex which was suspended in $50 \mu$ l of HEPES-saline, $\mathrm{pH}$ 7.0. After incubation at $20^{\circ} \mathrm{C}$, the PrPYP was removed from the complex by being washed twice with ice-cold buffer $A$ and twice with buffer B containing $50 \mu \mathrm{M}$ sodium orthovanadate at $4^{\circ} \mathrm{C}$. For determination of the phosphorylation state of the EGF receptor, SDS-gel sample buffer (33) was added to a portion of the immune complex and the suspended mixture was incubated in a boiling-water bath for $3 \mathrm{~min}$. After centrifugation, the supernatant was electrophoresed in an SDS-gel ( $7.5 \%$ acrylamide). The region of the gel containing the EGF receptor was excised and Cerenkov counted to quantitate the ${ }^{32} \mathrm{P}$ label remaining in the EGF receptor. An adjacent gel piece was excised, counted, and used as the background.

Tyrosine protein kinase assay. The EGF receptor-antibody complex was suspended in kinase reaction mixture containing $20 \mathrm{mM}$ HEPES ( $\mathrm{pH} 7.6$ ), $1 \mathrm{mM}$ dithiothreitol, $0.5 \%$ Nonidet P-40, $40 \mu \mathrm{Ci}$ of $\left[\gamma_{-}{ }^{32} \mathrm{P}\right] \mathrm{ATP}(3,000 \mathrm{Ci} / \mathrm{mmol}$; Dupont, NEN Research Products, Boston, Mass.), $1 \mu \mathrm{M}$ ATP, 50 $\mu \mathrm{M}$ sodium orthovanadate, $10 \mathrm{mM} \mathrm{MnCl}_{2}$, and $200 \mu \mathrm{g}$ of 


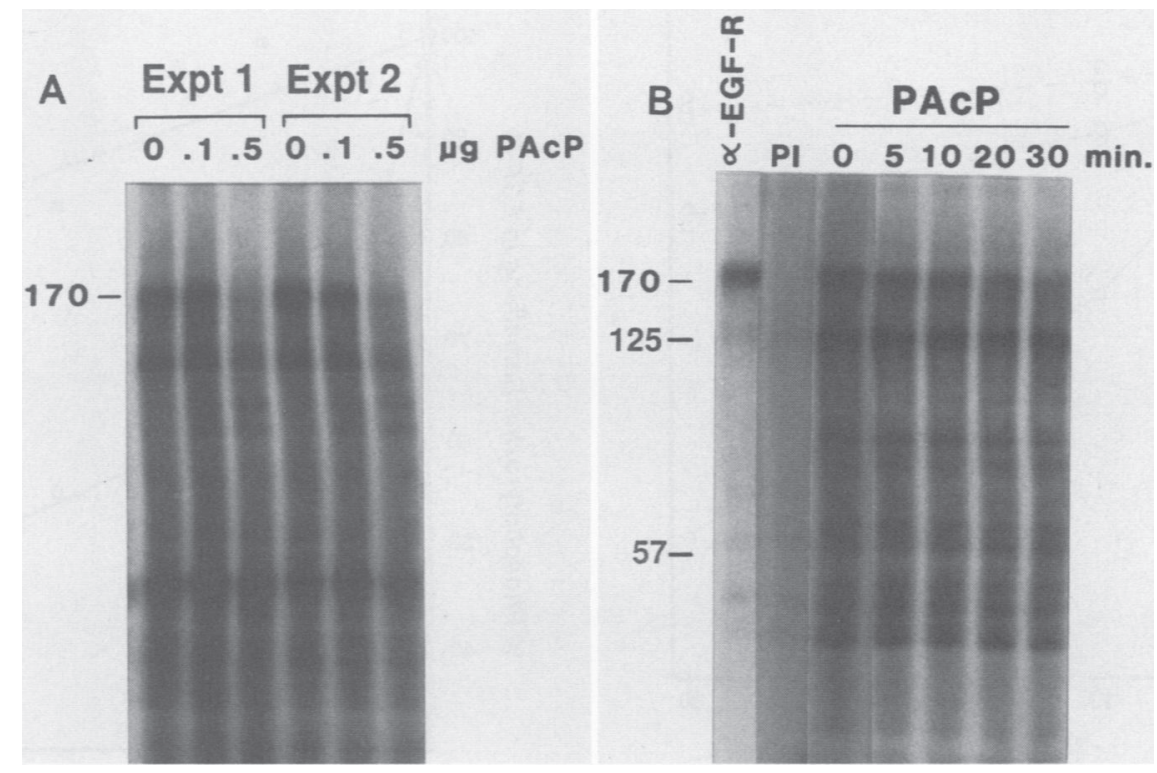

FIG. 1. Dephosphorylation of membrane vesicles by PAcP. Membrane vesicles prepared from DU145 cells which had been preincubated with EGF $(1 \mu \mathrm{M})$ at $20^{\circ} \mathrm{C}$ for 5 min were phosphorylated in a kinase reaction mixture containing $\left[\gamma^{32} \mathrm{P}\right] \mathrm{ATP}$ at $24^{\circ} \mathrm{C}$ for 10 min. The kinase reaction was stopped by the addition of EDTA $(0.2 \mathrm{M}, \mathrm{pH} 7.2)$ to a final concentration of $70 \mathrm{mM}$. Purified PAcP was added to the reaction mixture. (A) Experiments 1 and 2 represent duplicate experiments with $17 \mu \mathrm{g}$ of membrane proteins incubated with 0.1 and $0.5 \mu \mathrm{g}$ of PAcP. Dephosphorylation was performed by incubation at $24^{\circ} \mathrm{C}$ for $15 \mathrm{~min}$. (B) Proteins from a separate batch of membrane vesicles $(35 \mu \mathrm{g})$ were incubated with $1.0 \mu \mathrm{g}$ of PAcP. At different time points, a sample of reaction mixture was removed, boiled with an equal volume of $2 \times$ SDS sample buffer, and electrophoresed in a $7.5 \%$ polyacrylamide gel containing SDS. The protein was quantitated with protein dye (Bio-Rad Laboratories, Richmond, Calif.), and bovine serum albumin was used as the standard. The sample that was immunoprecipitated with antibody to the EGF receptor is designated $\alpha$-EGFR. PI designates the sample immunoprecipitated with preimmune serum. 170, 125 , and 57 mark regions of the gel corresponding to a molecular size of 170,125 , and $57 \mathrm{kDa}$.

angiotensin II (Sigma) and incubated at $34^{\circ} \mathrm{C}$ for $1 \mathrm{~min}$, that is, at the initial rate of reaction (data not shown). The reaction was stopped by incubation in a boiling-water bath for $3 \mathrm{~min}$, and the insoluble material was removed by centrifugation. The phosphorylated angiotensin in the supernatant was separated from other reaction components by paper electrophoresis at pH 4.4 (42).

Purification of PrPYP. PrPYP, formerly referred to as PAcP (37-40), was purified from human seminal plasma as described previously (41). The homogeneity of the enzyme was confirmed by polyacrylamide gel electrophoresis and high-performance liquid chromatography (38). Para-nitrophenyl phosphate (PNPP) was used as a substrate to monitor the phosphatase activity $(38,40,41)$. The $A_{410}$ was used to quantitate the formation of the product, para-nitrophenol.

\section{RESULTS}

PAcP dephosphorylates a 170-kDa phosphoprotein in plasma membrane vesicles of prostate carcinoma cells. We initially looked to the plasma membrane for potential substrates of PAcP because a form of the enzyme is associated with the plasma membrane $(17,35,39)$. We chose the DU145 prostate carcinoma cell line because it contains repressed levels of PAcP and tyrosine kinase activity that can be inhibited by the addition of PAcP to cell extracts (40). Plasma membrane vesicles from DU145 cells were phosphorylated in a kinase reaction mixture containing $\left[\gamma^{32} \mathrm{P}\right]$ ATP, and the kinase reaction was terminated by the addition of EDTA. Phosphoamino acid analysis indicated that the in vitro phosphorylated membranes contained 50 times as much phosphoserine as phosphotyrosine (data not shown). Purified PAcP was added and incubated with the phosphor- ylated proteins to identify potential substrates. Analysis of the products from this reaction by gel electrophoresis followed by autoradiography indicated that PAcP caused the removal of ${ }^{32} \mathrm{P}$ mostly from one protein of $170 \mathrm{kDa}$ (data not shown). However, the dephosphorylation rate was very slow. We initially considered the possibility that the $170-\mathrm{kDa}$ protein was the EGF receptor because the EGF receptor is a $170-\mathrm{kDa}$ protein that has been found in plasma membrane vesicles (12) and because EGF stimulates the growth rate of prostate carcinoma cells, indicating the presence of the receptor (45; unpublished observations). We therefore phosphorylated the membrane vesicles in the presence of EGF to stimulate tyrosine phosphorylation (12) of the EGF receptor and then treated the phosphorylated proteins with purified PAcP. The $170-\mathrm{kDa}$ protein was increased in phosphorylation by EGF treatment, and the rate of dephosphorylation of the $170-\mathrm{kDa}$ protein by PAcP was stimulated (data not shown). The increase in the rate of dephosphorylation may be due to the stimulation of tyrosine phosphorylation by EGF. Moreover, the extent of dephosphorylation of the $170-\mathrm{kDa}$ protein was proportional to both the concentration of PAcP (Fig. 1A) and the time of incubation with PAcP (Fig. $1 B)$. The $170-\mathrm{kDa}$ protein was the protein most visibly dephosphorylated for up to $30 \mathrm{~min}$ of incubation (Fig. 1B). At higher PAcP concentrations $(0.5 \mu \mathrm{g} / 100 \mu \mathrm{l})$, there was an additional protein of $125 \mathrm{kDa}$ sometimes observed to be dephosphorylated (Fig. 1A).

To examine the specificity of PAcP, we quantitated the extent of dephosphorylation of 170-, 125-, and 57-kDa proteins at different time points. The rate of dephosphorylation of the 170-kDa protein by added enzyme was about threefold faster than those of the 125- and 57-kDa phosphoproteins, 


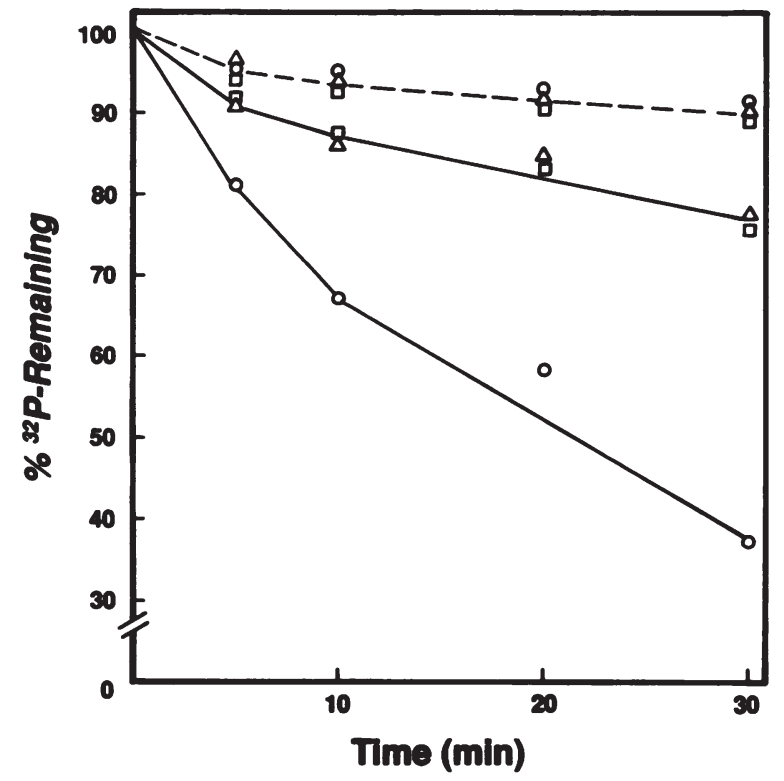

FIG. 2. Extent of dephosphorylation of the 170-, 125-, and 57$\mathrm{kDa}$ proteins by PAcP. The proteins in membrane vesicles were phosphorylated in a kinase reaction and then dephosphorylated in the presence (-) or absence (-- ) of purified PAcP. At different time points, the $170-\mathrm{kDa}(O), 125-\mathrm{kDa}(\triangle)$, and $57-\mathrm{kDa}(\square)$ proteins (Fig. 1B) were separated on an SDS-gel and localized by autoradiography. The gel pieces were excised and Cerenkov counted. An adjacent gel piece which did not contain phosphorylated protein was excised, counted, and used as the background. Each point is an average of four independent experiments in which the range is $\leq 5 \%$.

while there was no apparent difference in their dephosphorylation rates in the absence of PAcP (Fig. 2)

Although the $170-\mathrm{kDa}$ protein was selectively dephosphorylated by PAcP, it was not the predominant protein in the membrane vesicles. When the gel containing the vesicles was stained for protein, multiple bands were observed, but a $170-\mathrm{kDa}$ protein was not detected (data not shown). Furthermore, the $170-\mathrm{kDa}$ protein was not the major protein phosphorylated in the membrane vesicles (Fig. 1). Thus, PAcP appeared to selectively dephosphorylate the $170-\mathrm{kDa}$ protein among the membrane proteins phosphorylated in vitro.

Another commonly used phosphotyrosyl phosphatase, potato acid phosphatase, has been used to hydrolyze the phosphate from tyrosine 527 of cellular pp60 ${ }^{\text {src }}$ (13) and has been shown to dephosphorylate phosphotyrosyl histones about 50-fold faster than bovine PAcP (36). We therefore compared the reactivity of these two phosphatases at neutral $\mathrm{pH}$ with the phosphorylated membrane vesicle proteins from DU145 cells compared with a control sample incubated without added enzyme. PAcP dephosphorylated the 170-kDa protein about threefold faster than an equal amount of potato acid phosphatase (Fig. 3). In contrast, a similar proportion of the $125-\mathrm{kDa}$ phosphoprotein was dephosphorylated by PAcP (23\%) and potato acid phosphatase (19\%) during a 30-min reaction (data not shown).

The 170-kDa protein has properties of the EGF receptor. EGF stimulates the autophosphorylation and tyrosine kinase activity of its specific receptor $(12,29)$. Similarly, EGF stimulated the phosphorylation of the $170-\mathrm{kDa}$ protein in DU145 membrane vesicles (Fig. 4A), and this caused a twoto fivefold stimulation of the tyrosine kinase activity in the membrane vesicles (data not shown). To further test whether the $170-\mathrm{kDa}$ protein from DU145 cells was related to the

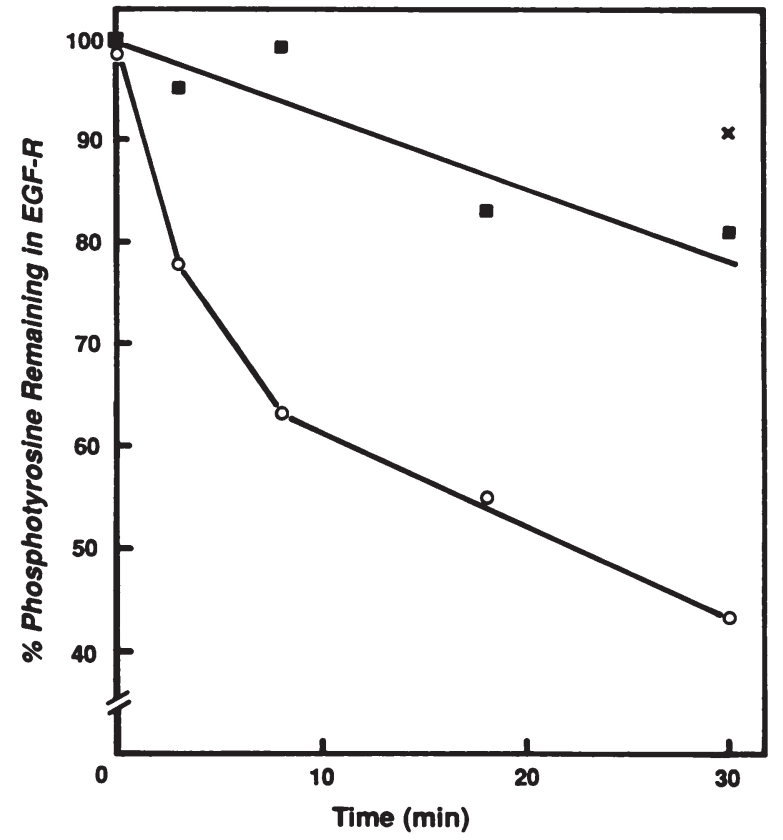

FIG. 3. Dephosphorylation of the $170-k D a$ protein by potato acid phosphatase and PAcP. The proteins in membrane vesicles $(35 \mu \mathrm{g})$ from DU145 cells were phosphorylated in the presence of $\left[\gamma^{32} \mathrm{P}\right]$ ATP and EGF as described in the legend to Fig. 1. A 1- $\mu$ g sample of $\mathrm{PAcP}(\mathrm{O})$ and of potato acid phosphatase $(\square)$ was added for different time periods. A sample of phosphorylated membrane proteins in the absence of an additional phosphatase $(\times)$ was incubated for $30 \mathrm{~min}$ to indicate the phosphatase-specific dephosphorylation. The 170$\mathrm{kDa}$ protein was localized in the gel by autoradiography, and the gel piece was excised and Cerenkov counted.

EGF receptor, we tested antibodies to the EGF receptor from A431 cells for reactivity. A $170-\mathrm{kDa}$ protein was specifically immunoprecipitated from DU145 as well as from A431 membrane vesicles (Fig. 1B and 4B). To determine whether the $170-\mathrm{kDa}$ phosphoprotein was heterogeneous in composition, we examined the material remaining following immunoprecipitation of the DU145 membranes. Greater than $80 \%$ of the ${ }^{32} \mathrm{P}$-labeled protein in the $170-\mathrm{kDa}$ region was immunoprecipitated by antibody specific for the EGF receptor (data not shown). Moreover, phosphorylation of the $170-\mathrm{kDa}$ protein from DU145 cells in the immune complex was stimulated in the presence of EGF (data not shown). Thus, the 170-kDa protein that was dephosphorylated by PAcP appeared to be the authentic EGF receptor.

PrPYP dephosphorylates the EGF receptor more efficiently at neutral pH. PAcP was previously found to hydrolyze small phosphomonoesters optimally at an acidic $\mathrm{pH}(39,41)$. However, dephosphorylation of the EGF receptor in membrane vesicles by PAcP occurred at neutral pH (Fig. 1 and 3 ). We therefore examined the pH optimum of dephosphorylation of the EGF receptor by PAcP. The EGF receptor in the solubilized membrane vesicles from DU145 cells was immunoprecipitated and autophosphorylated at tyrosine residues in the presence of EGF and $\left[\gamma^{32}\right.$ P]ATP. (Phosphoamino acid analysis indicated that greater than $90 \%$ of the label was in phosphotyrosine, consistent with previous observations [12].) PAcP was incubated with the immune complex at several $\mathrm{pH}$ values. Surprisingly, the EGF receptor was dephosphorylated by PAcP up to ninefold faster at neutral $\mathrm{pH}$ compared with $\mathrm{pH}$ 6.0. In comparison, PNPP, a small compound commonly used as PAcP substrate, was hydro- 


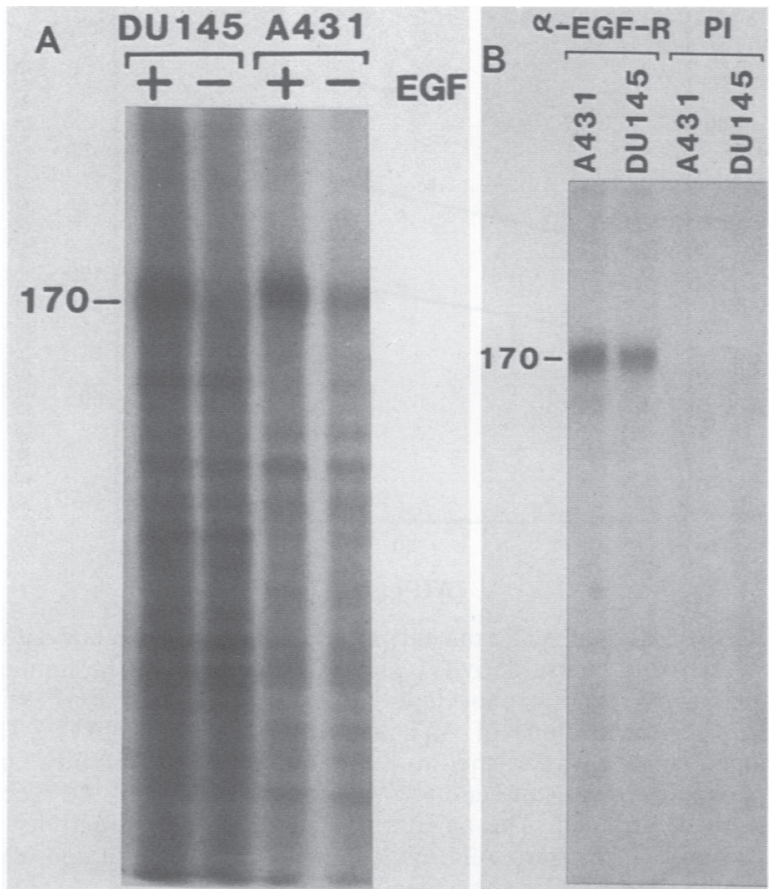

FIG. 4. Comparison of the $170-k D a$ protein from prostate carcinoma cells with the EGF receptor from A431 cells. (A) Preincubation with EGF stimulated the phosphorylation of the $170-\mathrm{kDa}$ protein (170). The membrane vesicles prepared from DU145 $(13 \mu \mathrm{g})$ and $\mathrm{A} 431(10 \mu \mathrm{g})$ cells were preincubated with $1 \mu \mathrm{M}$ EGF or $\mathrm{H}_{2} \mathrm{O}$ at room temperature for $5 \mathrm{~min}$ and then incubated in a kinase reaction at $0^{\circ} \mathrm{C}$. The reaction was stopped by the addition of an equal volume of $2 \times$ SDS-sample buffer, and the proteins were electrophoresed in an SDS-gel. The dried gel was autoradiographed for $16 \mathrm{~h}$ at $-70^{\circ} \mathrm{C}$. (B) The anti-EGF receptor antibody specifically precipitated the 170-kDa protein (170). Proteins in membrane vesicles $(40 \mu \mathrm{g})$ from DU145 cells were precipitated by anti-EGF receptor antibody as described in Materials and Methods. The washed immune complex was incubated in a kinase reaction in the presence of EGF and $\left[\gamma^{32} \mathrm{P}\right] \mathrm{ATP}$ and then electrophoresed in an SDS-gel. $\alpha-E G F-R$ and $\mathrm{PI}$ are defined in the legend to Fig. 1.

lyzed severalfold more rapidly at pH 6.0 (Table 1). We therefore propose that the name PAcP be changed to PrPYP to more accurately reflect the activity of this enzyme at physiological pH.

Dephosphorylation of EGF receptor causes decreased tyrosine kinase activity. To determine the effects of PrPYP on the kinase activity, we treated the autophosphorylated EGF receptor in an immune complex with phosphatase for $10 \mathrm{~min}$

TABLE 1. Effect of pH on dephosphorylation by PrPYP

\begin{tabular}{lccc}
\hline \multirow{2}{*}{ Substrate } & \multicolumn{3}{c}{ Activity of PrPYP } \\
\cline { 2 - 4 } & $\mathrm{pH} \mathrm{6.0}$ & $\mathrm{pH} \mathrm{7.0}$ & $\mathrm{pH} \mathrm{8.0}$ \\
\hline PNPP & $0.85(65)$ & $0.35(27)$ & $0.013(1)$ \\
EGF receptor & $140(1)$ & $1,200(8.6)$ & $800(5.7)$ \\
\hline
\end{tabular}

${ }^{a}$ The autophosphorylated EGF receptor in the immune complex was suspended in $50 \mu$ l of $0.1 \mathrm{M}$ HEPES buffer ( $\mathrm{pH}$ value as indicated) and a sample of purified PrPYP $(0.5 \mu \mathrm{g})$ in $5 \mu \mathrm{l}$ of saline. After incubation at $20^{\circ} \mathrm{C}$ for $10 \mathrm{~min}$, the phosphorylation state of the EGF receptor and the hydrolysis of PNPP by PrPYP were quantitated. The phosphatase activity with PNPP as the substrate was quantitated as para-nitrophenol formation $\left(A_{410}\right.$ per microgram). The phosphatase activity with EGF receptor as the substrate was counts per minute of ${ }^{32} \mathrm{P}$ removed per microgram of PrPYP.

$b$ The number in parentheses represents the fold increase.

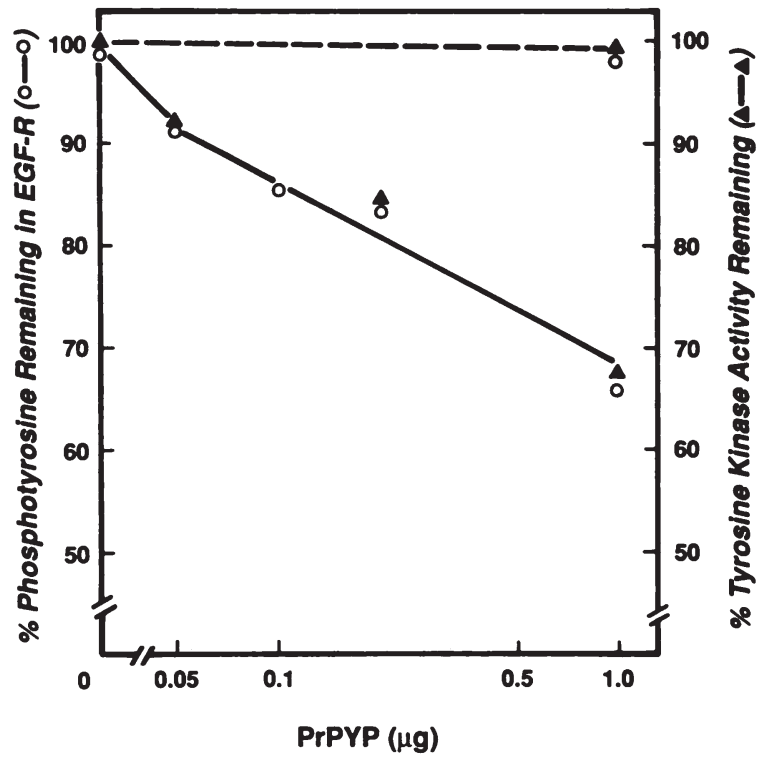

FIG. 5. Effect of PrPYP concentration on dephosphorylation and the kinase activity of the EGF receptor. The autophosphorylated EGF receptor in the immune complex was treated with PrPYP in the absence (-) or presence $(---)$ of vanadate $(100 \mu \mathrm{M})$ at $20^{\circ} \mathrm{C}$ for $10 \mathrm{~min}$. The phosphorylation state of the PrPYP-treated receptor was quantitated after SDS-gel electrophoresis, and the tyrosine kinase activity was determined by angiotensin phosphorylation as described in Materials and Methods.

at $20^{\circ} \mathrm{C}$. (Autophosphorylated kinases, such as the insulin receptor $[65,66]$ and cellular pp60 $60^{\text {src }}[13]$, have been effectively dephosphorylated in solid-phase complexes.) The immune complex was washed extensively to remove residual phosphatase, and the phosphorylation state was determined by quantitating the ${ }^{32} \mathrm{P}$ label associated with a sample of the receptor following SDS-gel electrophoresis. Under these conditions of maximum autophosphorylation at high ATP levels, we have calculated that about 2.4 to $2.5 \mathrm{~mol}$ of phosphate are incorporated per mol of EGF receptor. This is consistent with previous observations showing three sites of tyrosine phosphorylation in the autophosphorylated receptor from A431 cells (20). Moreover, preliminary observations on trypsin-digested receptor indicate three separate tyrosine phosphorylation sites on the EGF receptor from the DU145 cells (data not shown). The tyrosine kinase activity in a second sample was quantitated by measuring the phosphorylation of the exogenous substrate, angiotensin, in the presence of vanadate to inhibit any remaining PrPYP. PNPP was incubated with the immune complex without vanadate to detect residual phosphatase activity. No detectable PNPP hydrolysis was measured at $\mathrm{pH} 6.0$ in a 10-min reaction (data not shown). The extent of dephosphorylation increased with the concentration of PrPYP and closely corresponded to the extent of the decrease in tyrosine kinase activity (Fig. 5).

To test whether the phosphotyrosyl phosphatase activity of PrPYP caused inhibition of the EGF receptor kinase, we added $100 \mu \mathrm{M}$ vanadate, an inhibitor of PrPYP, to the immune complex together with the purified phosphatase. Dephosphorylation of the receptor did not occur, and the tyrosine kinase activity was not significantly affected beyond the loss in activity that occurred during incubation in buffer (Fig. 5). To test whether contaminating cellular phosphotyrosyl phosphatases were in the immune complex, we incubated the autophosphorylated receptor in $20 \mathrm{mM}$ HEPES 


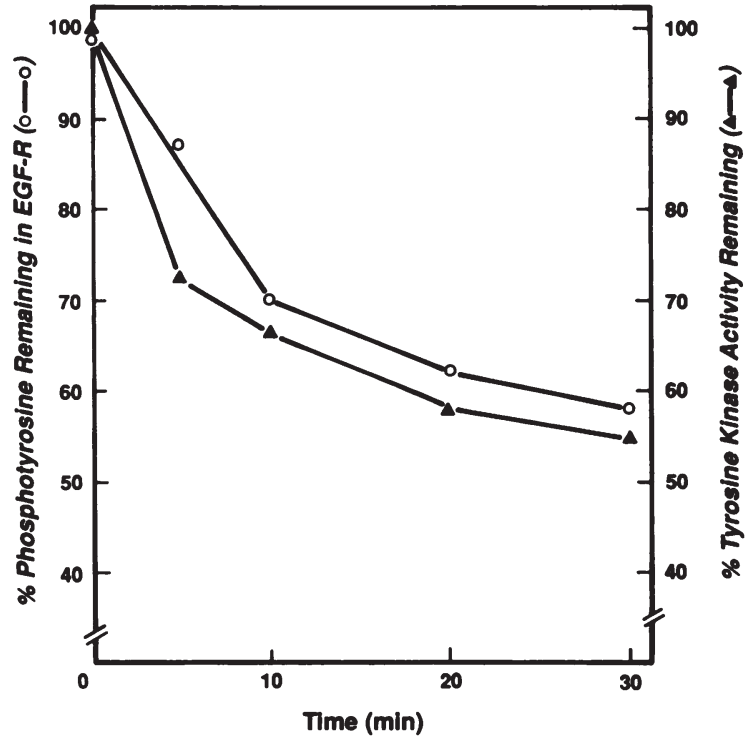

FIG. 6. Phosphorylation level and kinase activity of the EGF receptor following increasing time of incubation with PrPYP. The autophosphorylated EGF receptor in an immune complex was treated with PrPYP $(1 \mu \mathrm{g})$ at $20^{\circ} \mathrm{C}$ for various times. The phosphorylation state and the tyrosine kinase activity of the PrPYP-treated receptor were quantitated. The percent activity remaining was normalized to the control incubated without PrPYP.

(pH 7.0) for 10 min without vanadate and without PrPYP. Under these conditions, we detected little dephosphorylation of the EGF receptor (less than 5\%) (data not shown).

To quantitate the phosphatase-specific effects on the kinase activity, we incubated the autophosphorylated EGF receptor in the absence of PrPYP simultaneously with a sample that was incubated with PrPYP. Although little dephosphorylation of the EGF receptor from DU145 cells occurred in the absence of PrPYP, there was an approximate $50 \%$ loss of kinase activity following incubation for $30 \mathrm{~min}$ at $20^{\circ} \mathrm{C}$. This loss, which was observed at longer incubation times, probably reflected thermolability of the enzyme. Immunoprecipitated $\mathrm{pp} 60^{\text {src }}$ (13) and the insulin receptor (65) were also found to lose about $50 \%$ of their kinase activity upon incubation without phosphatase. Nevertheless, there was an additional phosphatase-specific loss in kinase activity that occurred with increasing time of incubation that closely paralleled loss of ${ }^{32} \mathrm{P}$ from the EGF receptor (Fig. 6). Phosphatase treatment brought the tyrosine kinase activity to about $30 \%$ higher than the basal activity.

Autophosphorylation of EGF receptor causes increased tyrosine kinase activity. Because inhibition of the kinase activity was caused by dephosphorylation by PrPYP, then addition of phosphate to tyrosines should enhance kinase activity. To test this possibility, we measured the initial rate of angiotensin phosphorylation by the autophosphorylated EGF receptor. The immunoprecipitated EGF receptor in the presence of EGF was first incubated for $10 \mathrm{~min}$ at $0^{\circ} \mathrm{C}$ in the absence or presence of various concentrations of ATP, and a sample was removed and analyzed in SDS-containing gels to assess the level of phosphorylation. In a separate sample, the ATP was washed from the immune complex, and the rate of angiotensin phosphorylation was measured at low ATP concentrations $(1 \mu \mathrm{M})$ in a 1-min reaction to limit additional autophosphorylation $(3,19)$. There was up to a sixfold increase in the kinase activity of the EGF receptor, and

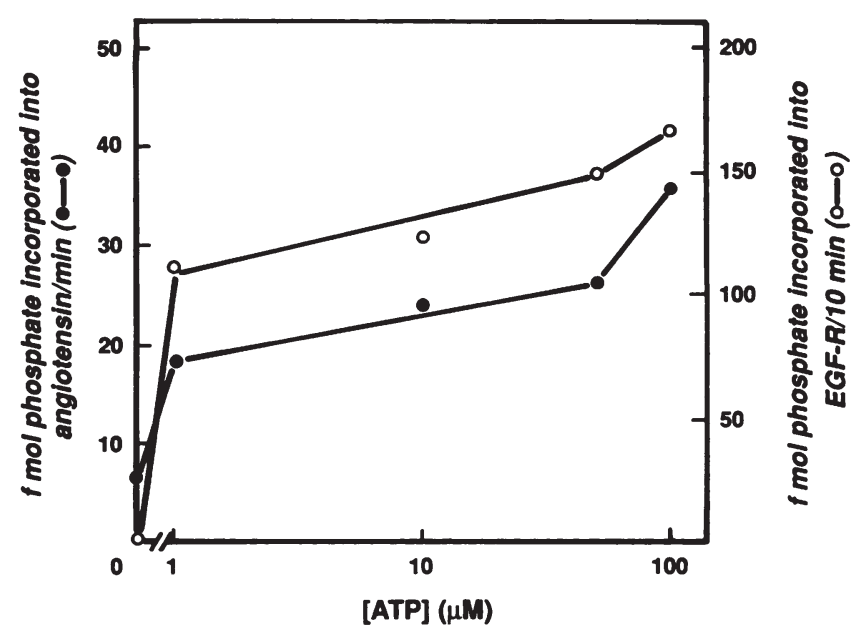

FIG. 7. Effect of ATP concentration during autophosphorylation on the tyrosine kinase activity. The EGF receptor in the immune complex was autophosphorylated in the presence of EGF with different concentrations of ATP and $10 \mu \mathrm{Ci}$ of $\left[\gamma^{-32} \mathrm{P}\right] \mathrm{ATP}$. The immune complex was washed to remove the reaction mixture, and the phosphorylation state and tyrosine kinase activity of the receptor were determined. The angiotensin phosphorylation activity of the receptor at the zero ATP concentration was quantitated after incubation with EGF in the absence of ATP.

about one-half of the increase (threefold) in both kinase activity and extent of autophosphorylation occurred at ATP concentrations of $1 \mu \mathrm{M}$ or less (Fig. 7). This may be explained by preferential phosphorylation of regulatory sites on the EGF receptor at low ATP concentrations (3). At higher ATP concentrations of 1 to $100 \mu \mathrm{M}$, the increased kinase activity continued to parallel the increased autophosphorylation of the EGF receptor.

As an alternative approach for examining the effect of autophosphorylation, the immunoprecipitated EGF receptor was incubated with ATP $(20 \mu \mathrm{M})$ at $0^{\circ} \mathrm{C}$ for various time periods to phosphorylate the receptor to different extents. One sample was removed to measure the level of autophosphorylation, and a second sample was used to measure the rate of angiotensin phosphorylation. Because some autophosphorylation occurred very rapidly and at very low ATP concentrations, we could not obtain a zero time point. The major increase in autophosphorylation (about 3.5-fold) was paralleled by increased tyrosine kinase activity $(\sim 40 \%)$ within the first $5 \mathrm{~min}$ (data not shown). Autophosphorylation of the EGF receptor continued, however, for up to $30 \mathrm{~min}$ of incubation with only a $20 \%$ increase in kinase activity. Possibly the initial phosphorylation occurred at sites that more strongly affected the kinase activity. Bertics and Gill (3) also observed that the initial autophosphorylation had a greater effect on the EGF receptor kinase activity. Because stimulation of tyrosine kinase activity occurred whether or not the receptor was incubated with EGF, the stimulation of tyrosine kinase activity was independent of EGF.

\section{DISCUSSION}

In the present study, PrPYP was found to selectively dephosphorylate the EGF receptor among several proteins phosphorylated in solubilized membrane vesicles from the DU145 prostate carcinoma cell line. The EGF receptor may have been preferentially dephosphorylated because it was a major tyrosine-phosphorylated protein in the membrane 
vesicles. Substrate specificity was unexpected, however. Biochemical studies have shown that PyPYP dephosphorylates phosphoserine in casein at about the same rate as it dephosphorylates phosphotyrosine in casein, although the $K_{m}$ for the former is about 50 -fold higher (38). The nearly 50 -fold-higher concentration of phosphoserine in the phosphorylated membrane vesicles should have compensated for effects caused by a lower affinity for PrPYP. This was not the case, and even after $30 \mathrm{~min}$ of incubation, the $170-\mathrm{kDa}$ protein was the only protein to be significantly dephosphorylated by PrPYP (Fig. 1 and 2).

Corresponding to dephosphorylation of the EGF receptor catalyzed by PrPYP, we observed a proportional decrease in the receptor kinase activity using the substrate angiotensin. The following results indicated that inhibition of kinase activity was caused by phosphotyrosine dephosphorylation. (i) The extent of inhibition using different concentrations of PrPYP paralleled the removal of phosphate from tyrosine. (ii) The extent of inhibition following increasing time of incubation with PrPYP corresponded to the extent of removal of phosphate from tyrosine. (iii) Inhibition did not occur when the phosphotyrosyl phosphatase inhibitor vanadate was added to the reaction simultaneously with PrPYP. (iv) Addition of phosphate to tyrosine by autophosphorylation stimulated the kinase activity of the EGF receptor.

It is also possible that PrPYP dephosphorylated constitutively phosphorylated serine and threonine residues in the EGF receptor $(21,29)$, thereby causing kinase inhibition. We doubt that this is the case. The extent of inhibition of kinase activity closely paralleled removal of phosphate from tyrosine. Moreover, under the conditions of our assays, little phosphoserine or phosphothreonine was dephosphorylated by PrPYP in the DU145 membranes. Finally, it seems more likely that removal of phosphate from the serine and threonines in the constitutively phosphorylated EGF receptor would stimulate kinase activity. Most of the same sites that are constitutively phosphorylated on the EGF receptor are enhanced in their phosphorylation after treatment of cells with tumor promoters, which results in inhibition of kinase activity $(11,16,31)$.

Although phosphatases have been used to probe the function of tyrosine phosphorylations in pp60 6 src $(13)$ as well as in the insulin receptor (65), this approach has not yielded consistent information on the function of autophosphorylation of the EGF receptor. There are several differences in our approach which may have allowed detection of inhibition of kinase activity by a phosphatase. (i) One possibility is the difference in the cell source of the EGF receptor. Other studies have consistently been conducted on the EGF receptor from A431 cells. Our unpublished observations and the work of others $(8,57)$ indicate that the membrane vesicles from A431 cells contained relatively high levels of phosphotyrosyl phosphatase, some of which appeared to be associated with the EGF receptor. The DU145 cells used in our studies, on the other hand, have repressed levels of PrPYP, which is the major phosphotyrosyl phosphatase in prostate epithelial cells $(37,39)$. This cell difference is borne out by the observation that with the EGF receptor immunoprecipitated from DU145 cells, less than $5 \%$ of the phosphate was hydrolyzed in a 10-min incubation with buffer, whereas under the same conditions $35 \%$ dephosphorylation occurred in the EGF receptor from A431 cells (unpublished observation). Contaminating phosphatase activity may confound attempts to determine the small effects of added exogenous phosphatase on kinase activity. (ii) The choice of phosphatase may also be important to obtain significant inhibition of kinase activity since it may be necessary to remove phosphates from critical tyrosines. PrPYP was particularly effective in catalyzing hydrolysis of phosphates from the autophosphorylated EGF receptor. The initial rate of hydrolysis was about three- to fourfold more rapid than that with another commonly used phosphotyrosyl phosphatase, potato acid phosphatase. (iii) Another detail of our experimental protocol that may have been important for detection of small changes in the kinase activity was the method used to quantitate the phosphorylated product. In our assays, the phosphorylated angiotensin was separated by high-voltage paper electrophoresis from the unincorporated $\left[\gamma-{ }^{32} \mathrm{P}\right] \mathrm{ATP}$ and other phosphorylated compounds (42). We found that acid precipitation or binding of the phosphorylated angiotensin to charged paper resulted in high backgrounds caused by trapped radioactive compounds that may obscure small changes in activity.

Although a greater than fivefold stimulation of kinase activity was observed as a result of autophosphorylation of the EGF receptor (Fig. 7), there was only about a 40 to $50 \%$ decrease in kinase activity following dephosphorylation of the receptor by PrPYP (Fig. 6). Similarly, inhibition of the insulin receptor tyrosine kinase activity by a phosphotyrosyl phosphatase was only about $50 \%$ and was disproportionate to the level of stimulation of kinase activity following autophosphorylation (65). One possibility is that ATP served to stabilize as well as to autophosphorylate the receptor kinase. It is also possible that some autophosphorylated sites were inaccessible to phosphatases in the solid-phase immune complex. Another factor that may have interfered with determination of the effect of PrPYP treatment was autophosphorylation of the receptor during assays of the kinase activity. As reported by Bertics and Gill (3), we observed a small amount of phosphorylation of the EGF receptor during the kinase reaction (data not shown). This may have returned some of the phosphate removed by PrPYP, thus restoring some of the kinase activity. Thus, the extent of phosphatase-specific inhibition may have been underestimated.

The stimulation of kinase activity that we observed following autophosphorylation of the EGF receptor from prostate carcinoma cells is in agreement with the results of Bertics and Gill (3), who observed stimulation using the EGF receptor from A431 cells. While they used the purified receptor in a soluble assay, we used receptor that was immobilized in an immune complex. Regardless of these differences in receptor preparations, our results are also similar in that the major extent of enhancement was observed at very low ATP concentrations (Fig. 7) and after very short periods of autophosphorylation (data not shown). These results indicate that the initial sites of phosphorylation are the most important in influencing kinase activity. While it cannot be completely ascertained why others have failed to see this stimulation, one possibility is that the rate of phosphorylation may have been determined when the reaction rate was not linear (21). It is at the initial rate of the reaction when the enzyme activity is most accurately determined (19). Another possibility is the use of peptide substrates with identical sequences to the autophosphorylation sites of the receptor $(21,25)$. If the model of Bertics and Gill $(3,59)$ is correct in that the autophosphorylation site(s) on the carboxy terminus of the receptor serves to block the active site, the kinetics of phosphorylation of these peptides may be different from those of other substrates.

PrPYP has previously been categorized as an acid phosphatase based on the $\mathrm{pH}$ optimum of dephosphorylation of 
organic phosphomonoesters $(37,39,41,51)$. Results presented here show that the PrPYP $\mathrm{pH}$ optimum depends on the substrate. When tyrosine-phosphorylated EGF receptor was used as the substrate, the rate of dephosphorylation was greatly accelerated at neutral $\mathrm{pH}$ compared with that at acid $\mathrm{pH}$ (Table 1). In marked contrast, hydrolysis of PNPP was more rapid at acid $\mathrm{pH}$. A similar result has been obtained with a phosphatase purified from bovine cortical bone matrix which exhibited an acid pH optimum with PNPP as the substrate and a neutral $\mathrm{pH}$ optimum when phosphotyrosinecontaining proteins were used as substrates (34). Thus, the division of phosphotyrosyl phosphatases into the categories of acid, alkaline, or neutral phosphatases and the determinations of their maximum velocities and $K_{m}$ values may not be meaningful since the $\mathrm{pH}$ optima may change depending on the substrate used.

An inverse correlation between PrPYP (formerly PAcP) and tyrosine protein kinase activity in prostate carcinoma cells has been observed (40). In addition, PrPYP inhibits the overall tyrosine kinase activity in lysates from cells with low levels of PrPYP (40). The possibility that the EGF receptor is an authentic substrate of PrPYP in prostate carcinoma cells is currently under investigation.

\section{ACKNOWLEDGMENTS}

We thank David Kabat for his thoughtful criticisms and Priscilla Burk for assistance with the preparation of this manuscript.

This work was supported by Public Health Service grant CA39641 from the National Cancer Institute to G.M.C. The page charges were paid for by the USC Comprehensive Cancer Center Urology Division Fund.

\section{ADDENDUM}

After submission of this manuscript, Bertics et al. (4) reported that mutation of tyrosine to phenylalanine at the major tyrosine phosphorylation site (Tyr-1173) of the EGF receptor blocked phosphorylation at this site. This mutation resulted in reduced kinase activity, particularly at nonsaturating levels of substrate. This finding further supports the concept that autophosphorylation of the EGF receptor positively modulates its kinase activity.

\section{LITERATURE CITED}

1. Ballou, L. M., and E. H. Fischer. 1986. Phosphoprotein phosphatases, p. 311-361. In P. D. Boyer and E. G. Krebs (ed.), The enzymes, 3rd ed., vol. 17. Academic Press, Inc., New York.

2. Bargmann, C. I., M. C. Hung, and R. A. Weinberg. 1986. Multiple independent activations of the neu oncogene by a point mutation altering the transmembrane domain of p185. Cell 45: 649-657.

3. Bertics, P. J., and G. N. Gill. 1985. Self-phosphorylation enhances the protein-tyrosine kinase activity of the epidermal growth factor receptor. J. Biol. Chem. 260:14642-14647.

4. Bertics, P. J., W. S. Chen, L. Hubler, C. S. Lazar, M. G. Rosenfeld, and G. N. Gill. 1988. Alteration of epidermal growth factor receptor activity by mutation of its primary carboxylterminal site of tyrosine self-phosphorylation. J. Biol. Chem. 263:3610-3617.

5. Bishop, J. M. 1985. Viral oncogenes. Cell 42:23-38.

6. Boivin, P., and C. Galand. 1986. The human red cell acid phosphatase is a phosphotyrosine protein phosphatase which dephosphorylates the membrane protein band 3. Biochem. Biophys. Res. Commun. 134:557-564.

7. Bolen, J. B., N. Rosen, and M. A. Israel. 1985. Increased pp60 $0^{\text {c-src }}$ tyrosyl kinase activity in human neuroblastomas is associated with amino-terminal tyrosine phosphorylation of the src gene product. Proc. Natl. Acad. Sci. USA 82:7275-7279.
8. Brautigan, D. L., P. Bornstein, and B. Gallis. 1981. Phosphotyrosyl-protein phosphatase. Specific inhibition by $\mathrm{Zn}^{++}$. J. Biol. Chem. 256:6519-6522.

9. Brown, D. J., and J. A. Gordon. 1984. The stimulation of pp60 $0^{\mathrm{v}-s r c}$ kinase activity by vanadate in intact cells accompanies a new phosphorylation state of the enzyme. J. Biol. Chem. 259: 9580-9586.

10. Chinkers, M., and J. S. Brugge. 1984. Characterization of structural domains of the human epidermal growth factor receptor obtained by partial proteolysis. J. Biol. Chem. 259:11534 11542.

11. Cochet, C., G. N. Gill, J. Meisenhelder, J. A. Cooper, and T. Hunter. 1984. C-kinase phosphorylates the epidermal growth factor receptor and reduces its epidermal growth factor-stimulated tyrosine protein kinase activity. J. Biol. Chem. 259:25532558.

12. Cohen, S., H. Ushiro, C. Stoscheck, and M. Chinkers. 1982. A native 170,000 epidermal growth factor receptor-kinase complex from shed plasma membrane vesicles. J. Biol. Chem. 257:15231531.

13. Cooper, J. A., and C. S. King. 1986. Dephosphorylation or antibody binding to the carboxy terminus stimulates pp $60^{\mathrm{c}-s r c}$. Mol. Cell. Biol. 6:4467-4477.

14. Courtneidge, S. A. 1985 . Activation of the pp60 ${ }^{\mathrm{c}-\mathrm{src}}$ kinase by middle $\mathrm{T}$ antigen binding or by dephosphorylation. EMBO J. 4: 1471-1477.

15. Coussens, L., C. Van Beveren, D. Smith, E. Chen, R. L. Mitchell, C. M. Isacke, I. M. Verma, and A. Ullrich. 1986. Structural alteration of viral homologue of receptor protooncogene fms at carboxyl terminus. Nature (London) 320:277280.

16. Davis, R. J., and M. P. Czech. 1985. Platelet-derived growth factor mimics phorbol diester action on epidermal growth factor receptor phosphorylation at threonine-654. Biochemistry 82: $4080-4084$.

17. Deguchi, T., T. M. Chu, S. S. Leong, J. S. Horoszewicz, and C. L. Lee. 1986. Effect of methotrexate-monoclonal anti-prostatic acid phosphatase antibody conjugate on human prostate tumor. Cancer Res. 46:3751-3755.

18. DiFiore, P. P., J. H. Pierce, T. P. Fleming, R. Hazan, A. Ullrich, C. R. King, J. Schlessinger, and S. A. Aaronson. 1987. Overexpression of the human EGF receptor confers an EGF-dependent transformed phenotype to NIH/3T3 cells. Cell 51:1063-1070.

19. Dixon, M., and E. C. Webb. 1979. Enzyme techniques, p. 7-11. In M. Dixon and E. C. Webb (ed.), Enzymes, 3rd ed. Academic Press Inc., New York.

20. Downward, J., P. Parker, and M. D. Waterfield. 1984. Autophosphorylation sites on the epidermal growth factor receptor. Nature (London) 311:483-485.

21. Downward, J., M. D. Waterfield, and P. J. Parker. 1985 Autophosphorylation and protein kinase $\mathrm{c}$ phosphorylation of the epidermal growth factor receptor: effect on tyrosine kinase activity and ligand binding affinity. J. Biol. Chem. 260:14538 14546.

22. Foti, A. G., H. Herschman, and J. F. Cooper. 1977. Isozymes of acid phosphatase in normal and cancerous human prostatic tissue. Cancer Res. 37:4120-4124.

23. Foulkes, J. F. 1983. Phosphotyrosyl-protein phosphatases. Curr. Top. Microbiol. Immunol. 107:163-180.

24. Foulkes, J. G., E. Erikson, and R. L. Erikson. 1983. Separation of multiple phosphotyrosyl- and phosphoseryl-protein phosphatases from chicken brain. J. Biol. Chem. 258:431-438.

25. Gullick, W. J., J. Downward, and M. D. Waterfield. 1985. Antibodies to the autophosphorylation sites of the epidermal growth factor receptor protein-tyrosine kinase as probes of structure and function. EMBO J. 4:2869-2877.

26. Heldin, C-H., and B. Westermark. 1984. Growth factors: mechanism of action and relation to oncogenes. Cell 37:9-20.

27. Horoszewicz, J. S., S. S. Leong, E. Kawinski, J. P. Karr, H. Rosenthal, T. M. Chu, E. A. Mirand, and G. P. Murphy. 1983. LNCaP model of human prostatic carcinoma. Cancer Res. 43: 1809-1818.

28. Huggins, C., and C. V. Hodges. 1941. Studies on prostatic 
cancer. I. The effect of castration, of estrogen and of androgen injection on serum phosphatase in metastatic carcinoma of the prostate. Cancer Res. 1:293-297.

29. Hunter, T., and J. A. Cooper. 1981. Epidermal growth factor induces rapid tyrosine phosphorylation of proteins in A431 human tumor cells. Cell 24:741-752.

30. Hunter, T., and J. A. Cooper. 1985. Protein-tyrosine kinases. Annu. Rev. Biochem. 54:897-930.

31. Iwashita, S., and C. F. Fox. 1984. Epidermal growth factor and potent phorbol tumor promoters induce epidermal growth factor receptor phosphorylation in a similar but distinctively different manner in human epidermoid carcinoma A431 cells. J. Biol. Chem. 259:2559-2567.

32. Klarlund, J. K. 1985. Transformation of cells by an inhibitor of phosphatases acting on phosphotyrosine in proteins. Cell 41: 707-717.

33. Laemmli, U. K. 1970. Cleavage of structural proteins during the assembly of the head of bacteriophage T4. Nature (London) 227:680-685.

34. Lau, K.-H. W., T. K. Freeman, and D. J. Baylink. 1987. Purification and characterization of an acid phosphatase that displays phosphotyrosyl-protein phosphatase activity from bovine cortical bone matrix. J. Biol. Chem. 262:1389-1397.

35. Lee, C. L., E. Kawinski, J. S. Horoszewicz, and T. M. Chu. 1986. Radioimmunodetection of human prostate adenocarcinoma xenografts using monoclonal antibodies to prostatic acid phosphatase. J. Tumor Marker Oncol. 1:47-59.

36. Leis, J. F., and N. O. Kaplan. 1982. An acid phosphatase in the plasma membranes of human astrocytoma showing marked specificity toward phosphotyrosine protein. Proc. Natl. Acad. Sci. USA 79:6507-6511.

37. Li, H. C., J. Chernoff, L. B. Chen, and A. Kirschonbaun. 1984. A phosphotyrosyl-protein phosphatase activity associated with acid phosphatase from human prostate gland. Eur. J. Biochem. 138:45-51.

38. Lin, M.-F., and G. M. Clinton. 1986. Prostatic acid phosphatase has phosphotyrosyl phosphatase activity. Biochem. J. 235:351357.

39. Lin, M.-F., and G. M. Clinton. 1987. Human prostatic acid phosphatase and its phosphotyrosyl-protein phosphatase activity. Adv. Protein Phosphatases 4:199-228.

40. Lin, M.-F., C. L. Lee, and G. M. Clinton. 1986. Tyrosyl kinase activity is inversely related to prostatic acid phosphatase activity in two human prostatic carcinoma cell lines. Mol. Cell. Biol. 6:4753-4757.

41. Lin, M.-F., C. L. Lee, S. S.-L. Li, and T. M. Chu. 1983. Purification and characterization of a new human prostatic acid phosphatase isoenzyme. Biochemistry 22:1055-1062.

42. Lin, M.-F., P. Lee, and G. M. Clinton. 1985. Characterization of tyrosyl kinase activity in human serum. J. Biol. Chem. 260: $1582-1587$.

43. Loor, R., M. C. Wang, L. Valenzuela, and T. M. Chu. 1981. Expression of prostatic acid phosphatase in human prostate cancer. Cancer Lett. 14:63-69.

44. Nelson, R. L., and P. E. Branton. 1984. Identification, purification, and characterization of phosphotyrosine-specific protein phosphatases from cultured chicken embryo fibroblasts. Mol. Cell. Biol. 4:1003-1012.

45. Peehl, D. M., and T. A. Stamey. 1986. Serum-free growth of adult human prostatic epithelial cells. In Vitro Cell. Dev. Biol. 22:82-90.

46. Purchio, A. F., S. K. Wells, and M. S. Collett. 1983. Increase in the phosphotransferase specific activity of purified Rous sarcoma virus $\mathrm{pp} 60^{\mathrm{v}-s r}$ protein after incubation with ATP plus $\mathrm{Mg}^{2+}$. Mol. Cell. Biol. 3:1589-1597.

47. Reif, A. E., R. M. Schlesinger, C. A. Fish, and C. M. Robinson. 1973. Acid phosphatase isoenzyme in cancer of the prostate.
Cancer 31:689-699.

48. Rosen, O. M., R. Herrera, Y. Olowe, L. M. Petruzelli, and M. H. Cobb. 1983. Phosphorylation activates the insulin receptor tyrosine protein kinases. Proc. Natl. Acad. Sci. USA 80:32373240.

49. Rotenberg, S. A., and D. L. Brautigan. 1987. Membrane protein phosphotyrosine phosphatase in rabbit kidney. Biochem. J. 243: 747-754.

50. Roussel, M. F., T. J. Dull, C. W. Rettenmier, P. Ralph, A. Ullrich, and C. J. Sherr. 1987. Transforming potential of the "c"-fms proto-oncogene (CSF-1 receptor). Nature (London) 325:549-552.

51. Schmidt, G. 1961. Nonspecific acid phosphomonoesterases, p. 37-47. In P. D. Boyer, H. Lardy, and K. Myrback (ed.), The enzymes, vol. 5. Academic Press, Inc., New York.

52. Sefton, B. M. 1986. The viral tyrosine protein kinases. Curr. Top. Microbiol. Immunol. 123:39-72.

53. Sherr, C. J., C. W. Rettenmier, R. Sacca, M. F. Roussel, A. T. Look, and E. R. Stanley. 1985. The c-fms proto-oncogene product is related to the receptor for the mononuclear phagocyte growth factor, CSF-1. Cell 41:665-676.

54. Shriner, C. L., and D. L. Brautigan. 1984. Cytosolic protein phosphotyrosine phosphatases from rabbit kidney. J. Biol. Chem. 259:11383-11390.

55. Sparks, J. W., and D. L. Brautigan. 1985. Specificity of protein phosphotyrosine phosphatases. J. Biol. Chem. 260:2042-2045.

56. Stone, K. R., D. D. Mickey, H. Wunderli, G. H. Mickey, and D. F. Paulson. 1978. Isolation of a human prostate carcinoma cell line (DU145). Int. J. Cancer 21:274-281.

57. Swarup, G., S. Cohen, and D. L. Garbers. 1982. Inhibition of membrane phosphotyrosyl-protein phosphatase activity by vanadate. Biochem. Biophys. Res. Commun. 107:1104-1109.

58. Tamura, S., T. A. Brown, J. H. Whipple, Y. Fujita-Yamaguchi, R. E. Dubler, K. Cheng, and J. Larner. 1984. A novel mechanism for the insulin-like effect of vanadate on glycogen synthase in rat adipocytes. J. Biol. Chem. 259:6650-6658.

59. Thompson, D. M., and G. N. Gill. 1985. The EGF receptor: structure, regulation and potential role in malignancy. Cancer Surv. 4:767-788.

60. Ullrich, A., L. Coussens, J. S. Hayflick, T. J. Dull, A. Gray, A. W. Tam, J. Lee, Y. Yarden, T. A. Libermann, J. Schlessinger, J. Downward, E. L. V. Mayes, N. Whittle, M. D. Waterfield, and P. H. Seeburg. 1984. Human epidermal growth factor receptor cDNA sequence and aberrant expression of the amplified gene in A431 epidermoid carcinoma cells. Nature (London) 309:418425.

61. Velu, T. J., L. Beguinot, W. C. Vass, M. C. Willingham, G. T. Merlino, I. Pastan, and D. R. Lowy. 1987. Epidermal growth factor-dependent transformation by a human EGF receptor proto-oncogene. Science 238:1408-1410.

62. Weinmaster, G., M. J. Zoller, M. Smith, E. Hinze, and T. Pawson. 1984. Mutagenesis of Fujinami sarcoma virus: evidence that tyrosine phosphorylation of p130 gag-fps modulates its biological activity. Cell 37:559-568.

63. Yam, L. T. 1974. Clinical significance of the human acid phosphatases: a review. Am. J. Med. 56:604-616.

64. Yonemoto, W., A. J. Filson, A. E. Queral-Lustig, J. Y. J. Wang, and J. S. Brugge. 1987. Detection of phosphotyrosine-containing proteins in polyomavirus middle tumor antigen-transformed cells after treatment with a phosphotyrosine phosphatase inhibitor. Mol. Cell. Biol. 7:905-913.

65. Yu, K. T., and M. P. Czech. 1984. Tyrosine phosphorylation of the insulin receptor beta-subunit activates the receptor-associated tyrosine kinase activity. J. Biol. Chem. 259:5277-5286.

66. Yu, K. T., and M. P. Czech. 1986. Tyrosine phosphorylation of insulin receptor beta-subunit activates the receptor tyrosine kinase in intact H-35 hepatoma cells. J. Biol. Chem. 261:47154722 . 